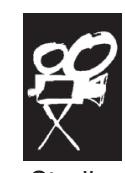

Studia

Filmoznawcze

37

Wrocław 2016

\title{
Станіслав Лігузінський
}

\section{Гелена викрадена або Польсько-українські зв'язки у «Вогнем і мечем» Єжи Гофмана}

DOI: $10.19195 / 0860-116 X .37 .10$

Без незалежної України немає незалежної Польщі, а без незалежної Польщі немає незалежної України

думка, яку приписують Сжи Гедройцю

Історія - предмет конструкції, місце якої не порожній гомогенний час, а час наповнений «актуальним теперішнім». Так, для Робесп'єра Стародавній Рим був минулим, що заряджене актуальним теперішнім, минулим, яке він виривав з історичного континууму. Французька революція розуміла себе як повернення Риму. Вона цитувала Стародавній Рим так само, як мода цитує одяг минулого. (...) Історично артикулювати минуле не означає пізнати його таким, «яким воно було насправді». Завдання в тому, щоб оволодіти спогадом, як він спалахує в момент небезпеки. Історичний матеріалізм прагне до того, щоб зафіксувати образ минулого таким, яким він несподівано постає історичному суб'єкту в момент небезпеки. Небезпека загрожує і змісту традиції, і тим, хто iii сприймає ${ }^{1}$.

Вальтер Беньямін. Про поняття історії

1 W. Benjamin, O pojęciu historii, [w:] tegoż, Anioł Historii, red. H. Orłowski, Poznań 1996, c. $414-415$. 
Сжи Гедройць і теза про кореляцію долі незалежних України і Польщі стали героями медійних дискусій, що супроводжували позаминулорічні події на Київському Майдані. Як серед прихильників, так і серед противників ангажування Польщі у справи східного сусіда, мовчазна домовленість про авторство цих слів була така сильна, що через деякий час вже говорили тільки про самого Гедройця, без їх пригадування. Побіжними пошуками неможливо встановити походження цієї цитати, тому б'юся об заклад, що редактор паризької «Культури» опинився у цих дискусіях в ролі вирваної з контексту полемічної фігури, незалежно від того, де, коли і чи взагалі висловлював згадану сентенцію. Заковика в тому, що приводом до ii медійного циркулювання була не спроба реконструкції геополітичних обставин, які вплинули на формування поглядів iii автора, а реальний військовий і самоідентифікаційний конфлікт, що торкається наших східних сусідів. Фронтом, на якому відбулася атрибутика цісї цитати, було не минуле, а - згідно з тезою Вальтера Беньяміна - сучасне, яке, опинившись у кризі, намагалося «оволодіти спогадом».

В інтерв'ю «Після мене хоч Потоп», яке Сжи Гофман дав кінокритику Яцкові Щербі, режисер подає аргументацію, яку вжив у полеміці з Лехом Качинським, захищаючи фабульну відмінність між фільмом «Вогнем і мечем» та його першоджерелом. Конфронтація стосувалася того, що режисер оминув звитяжну для польської зброї битву під Берестечком, якою завершується роман, і Гофман пояснив своє рішення примиренським характером фільму, що витікає, власне, з поглядів Сжи Гедройця. Здивований президент парирував: «Але ж Ви - поляк», на що режисер мусив підтакнути, додавши, що саме тому і вирішив так зробити. На завершення незадоволений співбесідник мовив: «Ви - митець, пане Майстре, політик - я»².

Абстрагуючись від теми неприйнятності політичних ухилів мистецького вислову, ці слова звучать винятково іронічно в контексті зусиль Єжи Гофмана щодо реалізації останньої частини трилогії Генріка Сенкевича, на яку він чекав більше 30 років, і зовсім не через мистецькі погляди.

Важко собі уявити кращу школу поєднання політики й кіно, аніж у Єжи Гофмана, який закінчив Всесоюзний інститут кінематографії (ВДІК) і має досвід постановки фільмів у ПНР. Говорячи про політичність фільмів режисера трилогії, маю, однак, на увазі не кон'юнктурну демагогію, необхідну, щоб обійти цензорів, а подану на початку цитату Вальтера Беньяміна, для якого історія мала писатися насамперед 3 почуттям відповідальності за тут і тепер. Таке розуміння ролі митця парадоксально зближує поставлений в дусі «творчої зради» «Вогнем і мечем» 3 трилогією, яка написана для змалювання Речі Посполитої Двох Націй не в іії реальному вигляді, а «для розради сердець».

2 J. Hoffman, J. Szczerba, Po mnie choćby i Potop [mobi], Warszawa 2015, c. 320-330. 
На естетичному рівні Гофман, живучи з фантазією і замилуванням сарматським розмахом, реалізує своє бачення розради сердець так, як і Сенкевич, тобто серед скреготу заліза, блиску шабель і мелодраматичних поглядів. У політичному вимірі його звертання до першої частини трилогії - це спроба розповісти про суб'єктність Польщі й України, спираючись на їхні взаємозв'язки.

Робота у 1997-1999 роках над фільм «Вогнем і мечем» випала на період формування спільного миротворчого польсько-українського батальйону під егідою НАТО (його послали зі стабілізаційною місією до Косова), підписання Леонідом Кучмою та Олександром Кваснєвським спільної «Декларації Президентів Польщі й України про порозуміння і єднання», а також організації компаративістичних семінарів, які проводили історики Військового історичного інституту у Варшаві та Волинського національного університету в Луцьку, присвячених найбільш контроверсійним проблемам спільної історії. У час, коли обидві держави намагалися зміцнити свою суверенну позицію, у взаємостосунках було вирішено залишити історію історикам ${ }^{3}$. Гофман доречно вписується у цю тенденцію, шукаючи у «Вогнем і мечем», згідно зі сформульованим Гедройцем постулатом, нагоди не тільки подискутувати про події кількасотрічної давнини, а й умови та можливості для гармонійної співпраці обох народів.

\section{ВОГНЕМ I ОЛИВОЮ}

Реалізація кінотрилогії виявилась для Єжи Гофмана справжньою 31-річною одісеєю. Гортаючи його спогади, натрапляємо на яскраві описи перешкод економічного, постановочного, технічного характеру, а також пов'язані $з$ політичним кліматом, що супроводжують кінематографістів. Процес, здійснений упродовж трьох десятиліть, міг взагалі не початись, якби автор наполягав на реалізації фільмів у хронологічному порядку - від «Вогнем і мечем» і до «Пана Володийовського». За рішення почати цикл з останньої частини було чимало чинників - сентиментальний, коли від пригод Малого Лицаря режисер почав свої пригоди з циклом Сенкевича, практичний - оскільки на «Потоп» гострив зуби сам Олександр Форд, а також драматургічний, який випливав 3 факту, що перша частина трилогії має найменш виразного головного героя. Однак Гофман, пам'ятаючи, що «Вогнем і мечем» був тією частиною триптиху, яка в часи цензури не дійшла до нього в Сибір, найперше керувався політичним прагматизмом.

3 T. Snyder, The Reconstrucion of Nations: Poland, Ukraine, Belarus 1569-1999, New Haven 2003 , c. $286-290$. 
Лавина ускладнень почалася вже в момент, коли після закінчення «Пана Володийовського» і «Потопу», осмілівши від успіху фільмів, на зустрічі кінематографістів країн народної демократії він натякнув, що має бажання завершити цикл. Першим обурився Сергій Бондарчук, погрожуючи: якщо Гофман дістане згоду на зйомки, він здійснить екранізацію «Тараса Бульби» Миколи Гоголя - повісті, що розповідає про долю Запорозької Січі, й нещадної до поляків так само, як «Вогнем і мечем» до наших сусідів. Після українців (Сергій Бондарчук - російський кінорежисер, а не український - прим. перекладача) прийшов час росіян, які сприймали твір Сенкевича як націлений на них. Врешті, коли невдовзі після зміни устрою в Польщі вже з'явилося зелене світло, щоб усунути білі плями в польсько-українських стосунках, проект зупинила Міністр культури демократичного уряду III Речі Посполитої. У наступні роки, коли перспектива постановки набирала вже реальних обрисів, за справу фільму вболівав заангажований в місії єднання народів Олександр Кваснєвський, і навіть згаданий автор сентеції, якою починається ця стаття, - Сжи Гедройць ${ }^{4}$.

Аби усвідомити, чому обов'язковий для польської молоді шкільного віку твір літератури викликав острах влади не тільки ПНР, а й III Речі Посполитої, з яких міркувань націоналістичні організації в Україні не хотіли пускати людей в кінотеатри, а поміркованіші кола противників влаштовували бойкот фільму, досить, ідучи слідами соціолога Яна Сови, дослідити історію редакції назви «Повстання Хмельницького» в англомовній Вікіпедії. Редагована користувачами інтернет-енциклопедія, що реєструє кожну спробу редагування тексту, є чудовим полігоном для огляду дражливої різниці в оцінці повстання Хмельницького серед поляків та українців. Тоді як наші рідні редактори подавали події другої половини XVII ст. як гучний за результатом бунт одержимого жагою помсти і хворобливими амбіціями антисеміта, який штовхнув східні рубежі Речі Посполитої в руки росіян, наші сусіди бачили в гетьманові провідника, який заклав підвалини у будівництво суверенної держави. Знаменно: допис був у черговий раз пересунутий з категорії «історія Польщі» до категорії «історія Росії», аби остаточно розміститись в каталозі, присвяченому Україні ${ }^{5}$.

Така ситуація виникає до певної міри 3 моделі вивчення історії, зорієнтованої на мілітарні успіхи, територіальні здобутки і приватні інтереси даного народу. Оскільки легко зрозуміти 3 цієї перспективи розбіжності в оцінці повстання, остільки непоодинокі випадки формулювання конфлікту в колоніальних категоріях зіткнення польської культури з непогамованою природою Дикого поля значною мірою можна приписати Генріхові Сенкевичу.

Суттєвий тут, безперечно, контекст написаної в часи анексованих територій Польщі трилогії, в якій козаки, шведи і татари становили загрозу, проти

4 J. Hoffman, J. Szczerba, Po mnie..., c. 320-330.

5 J. Sowa, Fantomowe ciało króla: peryferyjne zmagania z nowoczesna forma, Kraków 2011, c. 515-517. 
якої консолідується польський народ, а не представництво фактичних націй. Сугестивність оповіді разом із непослабною популярністю роману є причиною того, що негативні стереотипи в історичній свідомості читачів мають місце і досі. Занепокоєння цим фактом виражали і сучасники Сенкевича, зокрема Болеслав Прус, і пізніші критики, такі як Чеслав Мілош чи Вітольд Гомбрович, свідомі виняткового ідеологічного потенціалу популярної літератури. Судячи 3 результатів відвідування попередніх фільмів, що спиралися на канву трилогії, приступаючи до зйомок «Вогнем і мечем», Гофман не міг не бачити, що має в руках матеріал не меншого радіусу дії, і що це посилює тягар відповідальності.

\section{ТВОРЧА ЗРАДА}

На прес-конференції після нью-йоркської прем'єри фільму Гофман розповів, як замість того, щоб змінювати роман Сенкевича, мав уважно його прочитати ${ }^{6}$. Незважаючи на численні відступи від тексту роману, який проганяє сон лінивим до читання учням, детальний аналіз тих слів дозволяє стверджувати, що режисер, кажучи це, був недалекий від правди. Його концепція адаптації грунтувалась не на незв'язаному жонглюванні подіями і мотивами, а на пошуку простору інтерпретації там, де зображення і звук можуть увійти в контрапунктний зв'язок з текстом.

Усі ці кінематографічні зусилля Єжи Гофман здійснив у межах оповіді, конструкція якої у жодному разі не стала зменшеною модифікацією. Сенкевич починає свій роман сценою порятунку Хмельницького із влаштованої засідки. Прощаючись зі Скшетуським, який його звільнив, говорить йому своє справжнє ім'я і спокійно від’їжджає, аби на безпечній відстані заспівати козацьку пісню ${ }^{7}$. У фільмі майбутній призвідник повстання на тлі бузково-синьо-блакиного неба повідомляє, ким він $є$, після чого зображення світліє від вогненної кулі, з якої випливає назва «Вогнем і мечем».

Завершення обох історій увінчує оповідь всевідаючого наратора, що починається словами: «Спустошена Річ Посполита, спустошена Україна». У Сенкевича вони звучать відразу після вже згаданої переможної для військ короля Яна Казимира битви під Берестечком, коли «сам Хмельницький, зламаний, проклятий, своїм народом, шукав протекції сусідів», і розвинуте в такий спосіб: «Вовки вили на згарищах давніх міст і квітучий край нагадував великий цвинтар. Ненависть вросла в серця і отруїла побратимську кров - i ще довго

6 «The Polish Review» 2000, nr 3, c. 310.

7 H. Sienkiewicz, Ogniem i mieczem [e-book], opracowany na podstawie: Ogniem i mieczem, Warszawa 1974, c. 5-10. 
жодні вуста не вимовляли: “Хвала Богу на небі, а на землі мир людям доброї волі"»> 8 .

У фільмі недієгетичний наратор замінює цю проблему іншою, придуманою режисером: «Ненависть вросла в серця і отруїла побратимську кров. Через сто п'ятдесят років цариця Росії Катерина II розгромила Кримський ханат, ліквідувала Запорозьку Січ і спричинила занепад Речі Посполитої». Увінчує вона сцену розставання Скшетуського, Гелени і Богуна, після того, як Богунові подаровано життя. Князівна напружено спостерігає за козаком, який злітає верхи на коня, після чого на мить переводить погляд на свого обранця - ніби заполонив іiі сумнів. Коли знову спрямує очі на Богуна, вуста розтуляються у німому воланні, він уже в степу стає дибки на своєму карому коні. I якщо в цьому описі прозвучала лібідальна напруга, то не без приводу, бо ця сцена несе в собі виразний еротичний заряд. Якщо Ероса розуміємо за Ніцше як фігуру, що притягує крайнощі, то в цьому моменті є як зрив, так і утвердження мелодраматичного трикутника, що на нього спирався текст. Вибір одного 3 конкурентів супроводжується жалем, велить ретроспективно проблематизувати очевидний характер почуттів, які живили героїв оповіді.

Трактуючи нараційну рамку як вказівку для інтерпретації, можемо ризикнути і ствердити, що Сенкевич бачить у «Вогнем і мечем» передусім оповідь про програну цивілізаційну місію. У першій сцені він ідентифікує загрозу козаків, в останній показує наслідки легковажного бунту, що лишив після себе згарища, могили і душевну порожнечу.

Гофман ставить свій фільм у ситуації, в якій повстання Хмельницького сприймається як засадничий міф незалежного народу. Полум'яна куля з експозиції віщує трагічний за наслідками поєдинок, який буде живитися контроверсіями в наступні століття. Режисер, однак, звертає увагу на те, що, по суті, це тимчасовий конфлікт між двома суверенними сторонами, бенефіціантом якого є Росія, що приглядається до сутички.

\section{ВІДНЕСЕНІ 3 СІЧЧЮ}

Як зауважує Єва Гаузер, між романом і фільмом «Вогнем і мечем» можна помітити певні делікатні жанрові зміщення9 9 У час, що передував роботі над книжкою, Сенкевич жив у Сполучених Штатах і, схоже, був під впливом літературних вестернів. У долях польських шляхтичів, що перемірювали Дике поле, можна знайти відлуння ковбоїв, які перетинали прерії. Безпосередні поєдинки Міхала Володийовського з Богуном у першій частині трилогії і з Кміцем

8 H. Sienkiewicz, Ogniem i mieczem, c. 471.

9 E. Hauser, Reconstruction of national identity: Poles and Ukrainians among others in Jerzy Hoffman's film , With fire and sword”, «The Polish Review» 45, 2000, nr 3, c. 307. 
у «Потопі» приводять на думку сутички ковбоїв; наділені орієнтальними рисами постаті козаків і татар можна трактувати як еквівалент індіанців, а битва за Збараж нагадує героїчну оборону форту Аламо. Та найважливіша у цьому порівнянні глибинна структура, в якій репрезентована осадниками культура бореться за пріоритет з неуярмленою, дикою природою. Першу репрезентує в Сенкевича польська шляхта, другу - прибічники Хмельницького і корінне селянство України, яких автор називає дегуманізованим визначенням «чернь». У романі гноблена магнатами група показана як позбавлена суб'єктивності забита темна маса: «Чернь кричала, билась, давила одне одного, волаючи про пощаду, хоча ворог був поки що далеко» ${ }^{10}$.

Вживання Сенкевичем цього визначення $є$ емблематичним у його баченні конфлікту між Січчю і Річчю Посполитою. У території людей, чию мотивацію до бунту належало б розкрити, автор бачить тільки незайняте місце для господарювання. 3 цієї «черні» виокремлює козаків - їхню репрезентацію, необхідну з точки зору драматургії. Виступ супроти маси може бути знаком героїзму і мучеництва, як у випадку Лонгіна Подбип'ятки, що загинув від пострілу анонімних лучників, однак для змалювання конфлікту героям потрібні супротивники. Ігноруючи рацію «черні», Сенкевич може вільно будувати свій український «істерн», мотивуючи вибух повстання діями єдиного антагоніста - Богдана Хмельницького, - а також структурним конфліктом цивілізації і варварства.

У Гофмана початкова лінія конфлікту розвивається зовсім інакше. Згадувана Єва Гаусер у своїй статті про адаптацію «Вогнем і мечем» влучно зауважує, що фільм нагадує не так вестерн, як класичну мелодраму, а саме «Віднесені вітром» ${ }^{11}$. У романі Маргарет Мітчел й у фільмі Віктора Флемінга за цим романом на тлі громадянської війни простежуємо історію любовного трикутника, що розігрується між Скарлет О’Хара, галантерейним Ешлі Вілкесом та імпульсивним Реттом Батлером. Будучи переконана у своєму почутті до Вілкса, Скарлет ігнорує увагу Батлера, аби збагнути помилку, коли вже стане пізно. Що цікаво: Гофман перевернуто адаптує цю схему згідно зі своєю декларацією про уважне прочитання трилогії. Залишаючись вірним Сенкевичу, він не вкладає у вуста Гелени жодних слів, і не велить їй робити демонстративних жестів, що виражають вагання у виборі між двома залицяльниками, виявляючи це тільки на афективному рівні ${ }^{12}$. Весь драматизм цього конфлікту втілено в описаних вище поглядах, що супроводжують прощання героїв. Певною мірою тло любовних перипетій тут більше нагадує американську грома-

${ }^{10}$ H. Sienkiewicz, Ogniem i mieczem, c. 116.

11 E. Hauser, Reconstruction of ..., c. 310.

12 Афект розумію тут за Бряне Массумі як інтенсивність, яка не класифікована, емоція, яка проявилася, але нічим наперед не була обумовлена. Див: В. Massumi, Parables for the Virtual: Movement, Affect, Sensation, Durham 2002. 
дянську війну, у якій ставкою конфлікту було знищення рабства, ніж Сенкевичеву цивілізаційну місію.

Любовні перипетії трьох героїв і в повісті, й у фільмі, виконують, щоправда, роль метафори війни, яка труїть Річ Посполиту, однак у Сенкевича конгломерат переплетених пристрастей, що спирається на опозицію культури і природи, розсудку і дикості, а також чоловічості й жіночості служить єдиною мотивацією конфлікту. У книжці історичне тло роману визначає знову-таки фігура любовного трикутника, у який цього разу вписаний гетьман Богдан Хмельницький, дружина гетьмана і Данило Чаплинський. Як мовить Онуфрій Заглоба, порівнюючи повстання козаків з Троянською війною: «Хіба це і ця війна не за руду косу? Захотілося Хмелеві Чаплинської чи так само Чаплинському Хмельницької, а ми для їхньої грішної хіті карки крутимо» ${ }^{13}$.

Все складне сплетіння суспільно-політичних чинників, якими живився конфлікт в Україні, Сенкевич приховав під шаром безособової «черні», що після опублікування роману так прокоментував Болеслав Прус: «Це скелет жахіття, що називається козацькою війною. Матеріали до неї залишалися у всіх клаcax, у всіх стосунках України (...). У його [Сенкевича - авт.] романі не бачимо ані визискуваного народу, ані зневажених попів, ані ветеранів, що пригадують часи слави і рівноправності під знаменами Речі Посполитої (...). Він намалював тільки циферблат годинника, але коліщат і пружин не показав, тому з того, що говорить Скшетуський із Хмельницьким, можна зрозуміти, що тих пружин або не помітив, або не пізнав» ${ }^{14}$.

Гофман, оперуючи в межах оригінального тексту, не мав засобів для суб'єктивізації Сенкевичевої «черні». Замість цього він позбувається цілої групи саме так окреслених персонажів, а в результаті - i самого слова, роблячи козаків виразниками інтересів усього народу. Аби підкреслити цей зв'язок, він бере 3 книжки дві яскраві сцени з селянами, що делегують голос народу повстанцям. У першій - переповнені жагою помсти Курцевичам, навколишні селяни плюндрують і палять їхній родовий маєток в Розлогах, за що їм Ярема Вишневецький виносить смертний вирок. У другій - гості сільського весілля, куди навідується Заглоба з патрулем, споюють і зв'язують польських солдатів, щоб передати їх козакам. Ці події не звеличують кресових селян, однак виражають їхнє глибоке невдоволення - воно виникає 3 приниження, 3 того, що їх не визнають повноцінними, заодно ототожнюючи їх з повстанцями, які виступають проти поляків заради їхніх інтересів.

13 H. Sienkiewicz, Ogniem i mieczem, c. 274.

14 J. Szczublewski, Sienkiewicz. Żywot pisarza, Warszawa 1989, c. 138. 


\section{ЗІТКНЕННЯ ЦИВІЛІЗАЦІї}

Дбайливий відбір матеріалу, а також специфіка медіуму, відмінного від вербальних описів, сприяє тому, що нашпиговані негативом пасажі, звірячі порівняння й погордливі коментарі, якими виносить вирок Сенкевич, у фільмі підлягають редукції. Пиятика, насильницькі вибухи і гучне красномовство характеризують козацьке військо як зовні неотесане, але вільне і темпераментне. Прояв таких рис у поляків, і особливо в постаті Онуфрія Заглоби, який перед початком конфлікту представлений як компаньйон Богуна, що не нехтує нічним трунком, а в хвилину загрози не тільки вдається до підступів, а й виступає в одязі мандрівного діда, надає їм скоріше фамільярної подібності. Різниця між поляками й козаками у Єжи Гофмана має радше естетичний, ніж якісний характер - вона витікає не з діаметрального розходження самоідентичностей, а $з$ менш гарних манер і звичок, а також з вільнішої суспільної структури. Гофман добирає сцени з доступного у Сенкевича резервуару так, щоб підкреслити існування козацького етосу, наближеного у своїх проявах до польського романтичного ідеалу. Як з польського боку, так і з козацького неважко знайти бажаючих виконати надзвичайно ризиковані депутатські і розвідницькі місії - обидві сторони здатні до героїзму, готові на жертви заради честі, врешті як одні, так і другі, схильні схвалювати справедливі рішення верховної влади.

У Гофмана тактична майстерність нездійсненого гетьмана Речі Посполитої Богдана Хмельницького проявляється через талановитих підлеглих, таких, як Кривоніс. У битві під Жовтими Водами козаки проявляють військовий досвід і дисципліну, - встановлюючи табори, аналогічні до тих, які були в Гуситів, а також використовуючи несприятливі погодні умови, аби остаточно подолати спротив гусарів. У Сенкевича по той бік барикади стоїть не добре організована, інакша за звичаями національна група, а ті, що опановують сили природи: «Дикий і розбійницький народ, що здавна жив 3 насильства і нападів, (...) (який - доп. авт.) займав галявинки на рубежах i, лежачи на кордонах держави, як деспот на ланцюгу, погрожував нападникам. Тож зацвіло і зароїлося все. (...) Там, де колись ночами вітер дико грав очеретами та вили вовки і потопельники, тепер гуркотіли млини (...) Неозорий, одноманітний краєвид лісів і степів забарвився димами з коминів, золотими куполами церков і костелів - пустеля перетворилася на досить залюднену країну» ${ }^{15}$.

Фільм коригує це питання, пропонуючи картину сутички двох, не особливо віддалених культур. Чинником, що зміцнює таке враження, є українська мова, якою говорять актори. Ясна річ, в романі довгі пасажі чужою мовою вимагали б розбивання оповіді низкою посилань, однак відмінна система комунікації сприяє тому, що глядач сильніше відчуває особливість і потребу

15 H. Sienkiewicz, Ogniem i mieczem, c. 23. 
незалежності повстанців. Для польського глядача, що знає з історії політику русифікації чи германізації, мова становить важливий чинник самоідентифікації. Тому режисер не тільки дозволяє своїм героям говорити по-українськи, а й наділяє неписьменних персонажів роману, таких, як Юрко Богун, вмінням писати і читати. Цей факт має велике значення, адже показує існування навчальних осередків, а також козацької письменної і підготовленої еліти (частина провідників навчалися у православному Києво-Могилянському колегіумі). Творці фільму, показуючи схожість ціною різниці, зовсім ігнорують відмінність між римо-католицькою Річчю Посполитою і православною Україною, що, незважаючи на заснування унії в Бресті, було одним із двигунів напруженого повстання.

Весь суспільно-політичний спектр війни фокусується у фільмі на чотирьох постатях. 3 польського боку - це Ярема Вишневецький - догматик і католицький неофіт, чия військова хоробрість дорівнює пристрасному фанатизму. Князь справедливий, щедрий і дбайливий щодо своїх підданих, але глухий до аргументації експлуатованої людності України. Режисер нещадно підкреслює його догматичне засліплення, коли на спротив ксьондза нечесному трактуванню послів, які раніше вшанували недоторканість посольства Вишневецького, той відповідає: «Скшетуський був моїм послом, ти мене, ксьондзе, з бунтівниками рівняєш? Мордувати їх так, щоб чули, що помирають».

Режисер гостро засуджує небезпечний фундаменталізм князя, по-блюзнірськи легітимізований релігійною доцільністю, зіставляє стікаючі кров'ю, набиті на палі тіла козацьких герольдів зі сценою запевнення Бога у помсті: «Тобі матір найсвятіша, я підношу цю шаблю проти гультяйства, й доти іiї не складу, доки України не заспокою і бунтів селянських у крові не втоплю, так мені, пане Боже, допоможи. Амінь».

Широкий спектр козацьких інтересів репрезентують гетьман Богдан Хмельницький, Кривоніс і Богун. У першого, на противагу Сенкевичу, втілився популярний український актор Богдан Ступка. Оперуючи в межах тексту, Гофман і Ступка шукали можливості полеміки з Сенкевичем на грунті акторської інтерпретації цієї постаті. Обмежуючи кількість слів про гетьмана, що їх висловлюють треті особи, вони схиляють глядачів формувати власну думку на підставі його взаємодії з іншими героями. Богдан Хмельницький на екрані державний діяч, що оголосив війну магнатам в ім'я інтересів Речі Посполитої, яку репрезентує прихильний до козаків король Владислав IV Ваза. Він лояльний до своїх людей і гордовитий в очах супротивників. Необхідність захисту інтересів Січі штовхає його в обійми татар, однак бачимо, що це завдає йому дискомфорту. Наводячи свої аргументи в розмові зі Скшетуським, гетьман справляє враження справжнього трибуна народу, і на його тлі шляхтич скидається на наївного невігласа, нездатного порушити status quo в ім'я суспільного поступу. Адже Хмельницький представляє у «Вогнем і мечем» козацьку еліту, 
що прагне підняти підданство мешканців Січі, а також визнати ії незалежність - як третього члена Речі Посполитої Двох Націй (що стало одним із пунктів Гадяцької угоди, укладеної через 10 років після подій, зображених у «Вогнем і мечем»).

Кривоніс представляє інтереси реєстрових козаків, які звільнилися 3-під пансько-підданської системи, користуючись зброєю Речі Посполитої. Ця група в розрізі дій магнатів дбала про свою особисту свободу, адже магнати, які прагнули обмежити реєстр (а тим самим компетенцію і силу короля), мали б їм повернути відібране. Мужньо зіграна Мацеєм Козловським постать з іiі безцеремонністю, гордістю і рішучістю, надає козацькому повстанню контркультурних рис. Вільний, з люлькою в зубах, сильний герой постає яскравим контрастом до заплутаних в ієрархії польських шляхтичів, виражаючи ідеологічний вимір наростаючого конфлікту. Зіграний Олександром Домогаровим Богун представляє у фільмі нестійкий елемент, яким була зубожіла русинська шляхта. Запрошення на цю роль російського актора, додатково драматизує внутрішній конфлікт цієї постаті, приватний інтерес якої схиляє її до лояльності щодо Речі Посполитої, тоді як пориви серця будять в ній прагнення до незалежності. Домінуюча інтерпретація роману Сенкевича вбачає у постаті Богуна загрозу для місцевої польської самоідентичності. Себастіян Ягельський, аналізуючи польські патріотичні фільми, звернув увагу на наявні в них сексуальні табу, що торкаються «зв'язків “наших” жінок з чужими чоловіками, джерелом якого є суспільна турбота про збереження етнічної “чистоти” тих, які як потенційні матері втілюють і підтримують самоідентичність нації» 16 .

Наскільки в романі ототожнення Гелени з Полонією (жіночим символом Речі Посполитої) не викликає сумніву, настільки фільм дозволяє висунути іншу тезу, згідно з якою героїня «Вогнем і мечем» - це зворотний бік постаті Богуна, тож у боротьбі за її серце ставкою $є$ національна ідентифікація русинської шляхти, а в ширшому сучасному контексті - прихильність Європи. Ізабелла Скорупко, що втілилася в образ Гелени, була в Польщі в час постановки фільму символом міжнародного успіху. Її монументальна врода і білява коса (на відміну від кучерявої чорнявки в романі) відповідає загальнослов'янському канону краси, завдяки чому вона була однаково вірогідною як полька, як українка і як росіянка. Ці докази набувають значення у зіставленні з іiі походженням, а також з мовною і релігійною експресією. Гелена походить не 3 якогось зубожілого шляхетського роду, а $з$ династії Рюриковичів, які дали початок Русі. Зазвичай героїня розмовляє польською мовою, а в інтимній сцені молитви, наодинці з образом Богоматері, переходить на українську. Це може

16 S. Jagielski, (Melo)dramaty polskości. Naród i płeć w polskim filmie patriotycznym, [w:] Kino polskie jako kino narodowe, red. T. Lubelski, M. Stroiński, Kraków 2009, c. 65. 
свідчити не тільки про православне віросповідання, а й про приховане русинське коріння, якому дозволяє проявитися тільки на самотині.

Відповідно до Яна Сови, тогочасну Річ Посполиту скріплювала не національна єдність, а спільний інтерес польських, литовських і руських олігархів, які ототожнювали державу зі своєю кастою. Автор «Фантомного тіла короля» іде в своїх діагнозах ще далі, називаючи Річ Посполиту Двох Націй Польською кресовою компанією, чи «особливою як для Європи тих часів федерацією магнатських домініонів, що діяла згідно з ультрадемократичними засадами демократії учасників (але виключаючи більшість суспільних груп)» ${ }^{17}$. Така організація давала своїм членам можливість експлуатувати корінні землі польські й України, не зважаючи на короля і підданих.

У часи повстання Хмельницького майже вся русинська шляхта була полонізована, прикладом чого є Ярема Вишневецький, що в «Огнем і мечем» виступає людиною, яка змінила віросповідання і посилається на знайомство 3 батьком Гелени. 3 цього факту, а також 3 широких родинних прав через неї на землю можемо зробити висновок, що князь прийняв рішення про альянс 3 Річчю Посполитою. Однак його передчасна смерть поставила Гелену в ситуацію кризи ідентичності, коли маєтності, відібрані коштом конверсії, належать їй тільки віртуально, тоді як опір проти аподиктичної тітки маніфестується в приватній релігійній практиці. Вибір між Скшетуським і Богуном, який символічно увінчує вже описана сцена розставання, de facto $\epsilon$ вибором між раціональним класовим інтересом і витісненою національною ідентичністю. Вдаючись до анахронізму, в кульмінаційній сцені фільму можемо знайти знак сьогоднішнього поділу України на східну і західну частини як відгомін суперечностей між олігархами і мешканцями країни.

\section{РОБОТА ІДЕОЛОГІї}

Якщо поставити «Вогнем і мечем» супроти його російського візаві - повісті Миколи Гоголя «Тарас Бульба», стане видно, як на долоні, ідеологічний характер вибору, зробленого Геленою. У повісті Гоголя сина Тараса, який помирився з Річчю Посполитою в ім'я любові до польської князівни, визнано зрадником. Тоді як в колоніальній літературі прийняття автохтонної краси легітимізує колоніальну експлуатацію, підміняючи її виявом цивілізаційного піклування, 3 другого боку барикади той самий зв'язок сприйматиметься як огидний акт колаборації. Роман Сенкевича угрунтовує візерунок Польщі як колишньої імперії. Аби закріпити цей статус, вона потребує апробовуючого погляду периферії - Гелени, яка добровільно обирає Скшетуського і тим самим легітимі-

17 J. Sowa, Fantomowe ciało..., c. 34-44. 
зує фантазію колонізатора про вдячне сприйняття його цивілізаційної місії. У фільмі, згідно з декларацією Гофмана дотримуватись букви тексту, князівна робить аналогічний вибір, однак його не можна прочитати однозначно як знак домінування і доблесті. Режисер застосовує у «Вогнем і мечем» стратегію, описану Барбарою Клінгер як елемент, що узаконює т. зв. прогресивні переваги фільму ${ }^{18}$. Замість відвертої полеміки з ідеологічним зарядом, що міститься у тексті, Гофман унаочнює його носіїв, які повинні залишитись прозорими під прикриттям фабули. Згідно зі словами Луїса Альтюсера: «Тим, що дозволяє нам бачити мистецтво, тим, що робить його доступним нам у формі погляду, спостереження і відчуття (...), є ідеологія, з якої воно народжене, у яку занурюється, від якої відділяється як мистецтво і до якої звертається» ${ }^{19}$.

Чим вірогіднішим психологічно, прозорішим формально і більше підпорядкованим розвитку фабули є кіно, тим легше заховати свавільне вирішення його авторів. Але фільм «Вогнем і мечем» розбиває цей декор і, вдаючись до іронії, розшаровує фабулу, що випливає з роману, і конструйовану в адаптації оповідь ${ }^{20}$. Коли бачимо першу зустріч Скшетуського і Гелени, складається враження, що їх показано не через призму споріднення душ і шаленого вогню пристрасті, а на правах угоди. На їхніх, зображених крупним планом обличчях вимальовується вираз взаємного пізнавання, а не еротичне захоплення, - підтверджують характер почуття, яке зароджується, вже початкові такти «Думки на два серця», що ілюструють сцену. Починаючи з цього моменту, обоє дрейфуватимуть одне до одного не 3 появою здійснених справ, а незважаючи на них. В цьому випадку Гофман оголює укладання угоди, показуючи пасивність своїх героїв, які більшу частину фільму залишаються спостерігачами, а не учасниками подій. Емблематичною є битва під Жовтими Водами, у якій підтятий хворобою Скшетуський може тільки заохочувати польських гусар йти на відділи козацької піхоти. Контрапунктом до події на полі битви є гримаси радості і розчарування на обличчі польського шляхтича, тим самим Гофман жартівливо підкреслює його статус уболівальника у цій оповіді. Пасивний Скшетуський контрастує у фільмі 3 динамічним Богуном, який, незважаючи на рани, постійно змінює хід оповіді. На відміну від стриманого поляка, чия майстерність у фехтуванні не знаходить підтвердження на полі битви, а його найбільш героїчний вчинок - це втеча за допомогою хитрощів $з$ обложеного

18 B. Klinger, "Cinema/Ideology/Criticism” Revisited: The Progressive Genre [w:] Film Genre Reader IV, red. B.K. Grant, Austin 2012, c. 93-109.

19 Там само, с. 94.

20 Поділ на фабулу і оповідь здійснюю згідно з триступеневим поділом текст-оповідь-фабула, опрацьованим професором Мєкє Бал, в якому фабула є збиранням зв'язків між подіями, акторами, часом і місцем оповіді, а сама оповідь - нараційним опрацюванням фабули, презентованим у конкретний спосіб. Див: М. Bal, Narratology. Introduction to the Theory of Narrative, Toronto 1999. 
Збаража, запальний козак кидається у вир історії. Ми знайомимося з ним, коли він на своєму карому коні влітає галопом між Курцевичевою Геленою і Скшетуським. Уже в цій сцені Гофман порушує встановлену Сенкевичем ієрархію між героями. У повісті поляка представляє незворушний наратор:

«Це був ще дуже молодий чоловік, худий, чорнявий, дуже пристойний, iз сухорлявим обличчям і помітним орлиним носом. В його очах вимальовувалась жорстока фантазія і задерикуватість, але на обличчі він мав вираз шанобливий. Досить розкішні вуса i давно неголена борода надавали йому поважного, як на його вік, вигляду» ${ }^{21}$. А постать Богуна подано через сприйняття Скшетуського: «Раптом відчув, що один із вершників налягає на нього так сильно, що аж коні починають тертися боками. Розмова 3 князівною була перервана, бо пан Скшетуський, здивований і розгніваний водночас, обернувся до сміливця. При світлі місяця побачив двійко очей, які дивилися на нього зухвало, виклично і разом з тим насмішкувато. Ці страшні очі світились, як очі вовка у темному лісі. «Якого чорта? - подумав намісник. - Біс чи що?» 22 .

Фільм встановлює більш демократичний зв'язок між антагоністами, дозволяючи нам познайомитись із смаглявим вершником ще до того, як він приверне увагу поляка, без усього багажу звірячих та інфернальних порівнянь, які вживає Сенкевич. Послідовно вибудовуючи візуальну і фабульну опозиції між активністю Богуна і пасивністю Скшетуського, режисер розчленяє угоду, за якою протагоніст викликає симпатію своїми діями - звільняє зі скрутного становища обраницю, здобуваючи іiі любов. У фільмі любовний роман підшитий трагедією, у якій саме козак бореться з невблаганною долею і законами роду, здобуваючи прихильність глядачів (або, принаймні, подив у непоступливих). Неприязнь Гелени до Богуна $є$ не менш конвенційна, аніж іiї любов до Скшетуського. Хоча роман вказує на джерело цієї антипатії: «вона його ненавидить відтоді, як при ній чеканом розрубав людину. Кров капала між ним і ненависть виросла» $^{23}$.

Гофман ретельно ії оминає, використовуючи любовні прояви Богуна у боротьбі з романним стереотипом того «іншого», дикого суперника, на контрасті 3 яким увиразнюються позитивні риси героя.

\section{ПРОДУКУВАННЯ «ІНШОГО»}

Суб'єктивізуючи козаків, нюансуючи постать Богуна, а також позбуваючись безрідної примітивної «черні», Гофман, однак, стає перед проблемою створення природного противника для трагічно звільнених сторін. 3 епілогу дові-

21 H. Sienkiewicz, Ogniem i mieczem, c. 6.

22 Там само, с. 32.

23 Там само, с. 42. 
дуємось, що в перспективі століття тим противником виявиться Росія, проте в тексті першоджерела царська армія не відіграє жодної ролі, що не дозволяє вжити її в тому контексті. Режисер потребує сильного культурного контрасту - заповнення місця «Іншого», по-варварськи репрезентованого гомогенічною, нецивілізованою масою. Повністю минаючи конфлікт між католицтвом і православ'ям, наближуючи одне до одного романтичних козаків і поляків, він мусив створити для них виразну антитезу, на тлі якої їхня взаємна відмінність виглядатиме зникомою.

3 цією метою він використовує міф Польщі як «аntemurale christianitatis» - твердиню християнства. Як пише Норман Девіс: «Для кожного періоду на просторі історії від 1000 року до 1939 можна знайти висловлювання, які будуть доказом того, що Польща була, $є$ і залишиться надалі переднім фронтом західної цивілізації. У найдавніші віки бачили в ній захисника рубежів, які відділяли від пруських і литовських язичників, у новому часі - перешкоду, яка боронила доступ ісламові і московським схизматикам, у XX столітті - вартового шансів на лінії фронту боротьби з комунізмом. У всі часи призначене “місце в Свропі” для Польщі (...) було дуже чітко окреслене: антимурале, передмурале» ${ }^{24}$.

3 цієї перспективи природним противником стають не православні козаки, а кримські татари, що визнають іслам, або не так вони самі, як персоніфікований орієнтальний фантазм про Азію і Схід, підлеглих Тугай Бея і хана Іслам Гірея. Їхня відмінність конструйована не на базі хадисів, Корану чи конкретних культурних ідіосинкразій, а на відступах від католицької, польської норми. Встановлюючи свої «антимурале» між козаками і татарами, які в романі Сенкевича принципово між собою ідентифіковані, режисер не тільки естетично зміцнює відмінність між двома групами і драматизує несхожість думок, а й відпускає віжки фантазії, додаючи відсутні в повісті сюжети.

У взаємостосунках Богдана Хмельницького і татарських провідників з самого початку можна розгледіти диспропорцію сили. Гетьман укладає стратегічний союз із виразною неохотою - змушений до захисту своїх людей і обгрунтування спільних дій під вимогливим поглядом Тугай Бея. У розв’язному характері зіграної Даніелем Ольбрихським постаті відбивається цілковита байдужість до рації повстанців. Гетьман поглядає на нього то з напругою, то з огидою, коли, дякуючи за послугу Скшетуському, мусить замінити почесні аргументи мішками золота. Тоді як поляки і козаки у переважній більшості керуються почуттям особистої гідності і власною думкою, татар мотивує хтивість, і їхня лояльність зникає з першими ознаками поразки під Збаражем. Гофман послідовно показує цю різницю у побутових сценах. У час найвищого стратегічного тріумфу під Жовтими Водами бачимо мешканців Січі - 3 їх

${ }^{24}$ N. Davies, Boże igrzysko: Od początków do roku 1795, Kraków 1992, c. 219. 
характерними довгими возами, оселедцями на поголених головах і шароварами, підв'язаними оксамитовими поясами. Боягузливе вбивство Подбип'ятки здійснюють уже вдягнуті в шкури і в характерні ковпаки татари. Пронизане стрілами невірних тіло Лонгінуша наводить, зрештою, на думку про іконографічно подану постать святого Себастіана, розстріляного з лука під самотнім деревом.

У своій орієнталістичній фантазії Гофман іде ще далі, протиставляючи романтичний гетеронормативний ідеал, що вибудовує трикутник мелодрами, сексуальному ексцесові. Хмельницький, що веде переговори з ханом, 3 виразною несхвальністю оглядає знаки уваги, які Іслам Гірей виявляє молодому підлеглому Субгазему, тоді як Гелена з огидою відпихає від себе Горпину, яка нападає на неї. Гомосексуалізм тих двох - це вже «licentia poetika» режисеpa, який зміцнює бінарну опозицію цивілізації і дикості, героїзму і боягузтва, жорстокості і милосердя, заодно демонізуючи негетеронормативну сексуальність. Змальована в романі як статурна й наділена пронизливим голосом, але «красна» ${ }^{25}$ Горпина, в руках режисера замінена на відворотного носія усього неприйнятного - сексуального вампіра, якому Жендзя забиває кілка ${ }^{26}$.

Гофман дозволяє проявитись власному, неодноразово вираженому упередженню ${ }^{27}$, і підкоритися в багатьох інших пунктах реконструйованій схемі колоніального роману, де чужинці часто $є$ носіями сексуального ексцесу. Відважившись на такі зміни, він парадоксально відтворює вроджене протиставлення, вписане у міф Польщі як пристановища толерантності і премудрого християнства, на що звертає увагу Норман Девіс: «Ця ухвала приховувала в собі однак доказ певної крихкої суперечності. Якщо католицька Річ Посполита була по суті “пристановищем толерантності”, то це могло статися тільки завдяки наявності в ній власних дисидентів; якщо ж громадськість іновірців була така велика, що аж треба було їй толерувати, то Річ Посполита не могла бути однорідно католицька» ${ }^{28}$.

Йдучи далі шляхом британського історика, треба погодитись, що інтереси кресів, можна визнати спільними з інтересами Речі Посполитої тільки тоді, якщо вони з'єднані під егідою «головної багатоетнічної і багатокультурної суспільно-політичної ідентичності». Якщо, конструюючи цю ідентичність, виключити критерії сексуальності, це буде запереченням іiї інклюзивної, толеруючої формули. Це є істотним тому, що в час постановки фільму як головного

25 Michał Wołodyjowski o Horpynie. Patrz: H. Sienkiewicz, Ogniem i mieczem, c. 379.

26 У романі він ставить на тілі Горпини хрест.

27 Жінки взагалі займають особливе місце в житті кожного чоловіка. Підкреслимо: нормального чоловіка; довго був шанувальником (...) Юлія Цезаря. Перечитав майже всі книжки на цю тему, хоча його бісексуальні схильності не поділяв. Джерело: J. Hoffman, J. Szczerba, Po mnie...

28 N. Davies, Boże igrzysko, c. 221. 
політичного проекту, до якого долучилася Польща і Україна, він ототожнювався з Свропейським союзом. Гофман актуалізував у «Вогнем і мечем» парадокс, закладений у міфі про Польщу як підвалину християнства, який того разу вмістився в утвердженні одночасної приналежності до ліберального Заходу і сексуальної дискримінації, що підважує ту ідентичність.

\section{ЕпІлог}

У цій суперечності, жертвою якої падає сам фільм, криється і драма його героїв. Незважаючи на те, що у фінальній сцені доходить до традиційного створення пари, ніхто не тріумфує. Гофман видобуває з тексту переконання, що всі троє персонажів мелодрами одне одного потребують. Динаміка цього зв'язку дозволяє кожному з ії членів доокреслити і перекроїти себе. Прекрасна Гелена з нікому невідомої власниці великого маєтку з точки зору Богуна і Скшетуського, перетворюється у жадану постать, і знаходить в одному із залицяльників стабільне опертя, а в другому - джерело вітальності і пристрасті. Суперники в боротьбі за серце князівни провокують один одного до дії-козак вириває поляка $з$ його ситої пасивності, аби самому знайти виразний вектор поступу в своїй граничній ситуації конфлікту лояльності. Адже тим, що приводить до переповненого жалем і розчаруванням фіналу, є не сам бурхливий любовний роман, а його категоричні, ексклюзивні і суворі правила. Замість взаємного порозуміння, компромісу, пошанування вибору і діалогу, ним керує деструктивна агресія, ворожість і егоїзм.

Якщо історію, а особливо історію великої кінематографічної продукції, яка досить довго чекала на слушний час і місце реалізації, потрактувати за Беньяміном як «спробу заволодіти пригадуванням (...) ухопити образ минулого, який зненацька накидається історичному суб'єкту у хвилину загрози», то неважко розпізнати сучасних персонажів мелодрами Сжи Гофмана. Багата і жадана Європа, яка на етапі реалізації фільму, вже розпочала переговори з Польщею, і роздерта між Сходом і Заходом Україна, чиє молоде вітальне покоління прагне того самого. Звернення до моменту, що значною мірою ініціював розпад фантазматичного золотого віку Речі Посполитої Двох Націй, у Єжи Гофмана обтяжене значно меншим обладунком ностальгії, ніж у Сенкевича. Може скластися враження, що він поставлений не для розради сердець поляків картиною колишньої потужності їхньої батьківщини, а для попередження. Якби Річ Посполита не спіткнулася об свою класову ексклюзивність, егоїзм, мегаломанію і шкідливу ворожість, можливо, була б у стані створити провісницький проект «...багатоетнічної і багатокультурної суспільно-політичної ідентичності», здатної залагодити інтереси поляків, українців, литовців і русинів, кладучи підвалини під європейський союз «avant la letter». Проте цей 
анахронізм не має викликати історичний сентимент, а тільки гедройцівську за духом констатацію потреби діалогу, а також співпраці із сильним і незалежним українським партнером.

\title{
KIDNAPPED HELENA, OR POLISH-UKRAINIAN RELATIONS IN JERZY HOFFMAN'S WITH FIRE AND SWORD
}

\begin{abstract}
Summary
Being one of the most beloved epics and once a vessel of patriotism, written famously to strengthen the hearts of Poles during the partition of the country, Henryk Sienkiewicz's Trilogy still stirs a lot of controversies among other nations depicted in the novels. Considering Poland's past colonial entanglement with Ukraine, difficult unresolved issues in our common history and disdainful descriptions of Cossacks, none of the series' parts proved to be as problematic to adapt to the screen as With Fire and Sword. Being able to finally make the movie and complete his lifetime project of filming Trilogy after 31 years of struggle, a Polish film director Jerzy Hoffman faced a serious challenge of preserving the spirit of the novel without enhancing reciprocal prejudices between the nations. In my article, I try to identify textual and visual strategies employed by the director in order to refract disturbing colonial underpinning of Sienkiewicz's With Fire and Sword. Analysing the narrative frame, genre shifts, construction of the characters and ideological implications of certain aesthetic choices, I argue that to a certain degree Hoffman managed to transform the novel's classic imperialistic narrative of mission civilisatrice - providing rationale for colonization on the grounds of social evolutionism and civilizational progress - into a subversive melodrama personifying feuding nations as equal subjects. By doings so, the director managed to scale down nostalgic yearning for the bygone power and magnitude of the Polish-Lithuanian Commonwealth, in order to redirect audience's attention to the necessity of maintaining good relations with our sovereign neighbour.
\end{abstract}

Translated by Stanisław Liguziński 